\title{
Transmission of the Greek crisis on the sovereign debt markets in the euro area
}

\author{
Oussama Kchaou $^{1}$ (D) Makram Bellalah ${ }^{1}$ (D) Sofiane Tahi ${ }^{1}$
}

Accepted: 8 January 2021 / Published online: 23 November 2021

(c) The Author(s), under exclusive licence to Springer Science+Business Media, LLC, part of Springer Nature 2021

\begin{abstract}
We test for the contagion effects stemming from the Greek debt crisis in the daily 10-year sovereign bond yield spreads in nine Economic and Monetary Union (EMU) countries. To this end, we estimate the dynamic conditional correlation (DCC) model of Engle (2002) from January 01, 2003 to December 31, 2015. In addition, we calculate and plot the upper and lower bounds of the confidence interval for each DCC series. To the best of our knowledge, this approach of Kchaou and Bellalah (2020) has never been used to study the contagion of the subprime and Greek crises between the 10-year sovereign bond yield spreads of the main EMU countries. Consequently, this approach enables us to compare our results with those of previous works based on other methods. It also offers useful insights to policy makers to address the contagion effect through the implementation of adequate measures. Although the Greek spread played the role of a global factor for the majority of countries during the observation period, the results invalidate the existence of contagious episodes resulting from the Hellenic crisis. We justify these findings either by the weakness of the weight of the Greek economy in the euro area or by the effectiveness of the unconventional monetary policies taken by the European Central Bank (ECB), the bailouts for Greece in 2010, 2012 and 2015 and the austerity measures and structural reforms implemented by the governments of EMU countries. Moreover, DCC between Greece and the other countries have shown a downward behavior during the acute phases of Greek crisis, suggesting a disintegration of the Hellenic bond market with those of other euro area countries during periods of financial turmoil. Furthermore, the results indicate that the subprime crisis affected a large part of these markets well before the bankruptcy of Lehman Brothers. All these findings provide valuable information for international investors, central bankers and policymakers.
\end{abstract}

Keywords Contagion · Greek Crisis · GARCH-DCC · Confidence Interval

Makram Bellalah

Makram.bellalah@u-picardie.fr

Oussama Kchaou

Oussama.kchaou@u-picardie.fr

Sofiane Tahi

Sofiane.tahi@u-picardie.fr

1 LEFMI Lab, University of Picardie Jules Verne, Amiens, France 


\section{Introduction}

Since the birth of the Eurozone in 1999, the 10-year sovereign bond yield spreads of the EMU countries have strongly converged. The underlying market perception was that financial integration in the euro area had eliminated the ability of markets to distinguish between the creditworthiness of different sovereign issuers. This was considered as a major success of the single currency (Giordano et al. 2013) and the reflection of a successful financial integration (Abad et al. 2010). However, at the end of 2009, the economic and financial landscape witnessed the onset of the Greek crisis. Since then, the 10-year sovereign debt yield spreads of the EMU countries have started to increase as shown in Fig. 1. This phenomenon has mainly affected the peripheral countries of the Eurozone.

This fact leads us to ask the following question: does the contagion stemming from the Greek crisis explain, to some extent, the increasing path of sovereign bond yield spreads on the EMU sovereign debt markets?

Despite the existence of abundant theoretical and empirical literature dealing with the transmission of crises, the definition of contagion has changed from one study to another. Eichengreen et al. (1996), Glick and Rose (1999), Kaminsky and Reinhart (2000), Caramazza et al. (2004) and Haile and Pozo (2008), among others, describe a crisis in country "i" as contagious if it increases the probability of occurrence of another crisis elsewhere. Masson (1998) presents the contagion effect as the transmission of a crisis from one country to another for reasons unexplained by macroeconomic fundamentals. For Dornbusch et al. (2000), contagion is the transmission of shocks from one country to another observed via co-movements between exchange rates, stock prices, sovereign spreads and capital flows. Goldstein (1998) introduced the concept of "wake-up-call" contagion, in the context of the Asian crisis, which arises when news from a country "i" lead investors to reassess the risks/financial assets of other countries with similar fundamentals. Forbes and Rigobon (2002) define contagion as a significant increase in heteroscedasticity-adjusted correlations between markets following a crisis in one or a group of them. To summarize, Pericoli and Sbracia (2003) present the five most mentioned definitions in the financial literature. As for the definitions of contagion, previous studies show the use of several methods to analyze this phenomenon such as ARCH-GARCH models (Rotta and Pereira 2016; Alexakis and Pappas

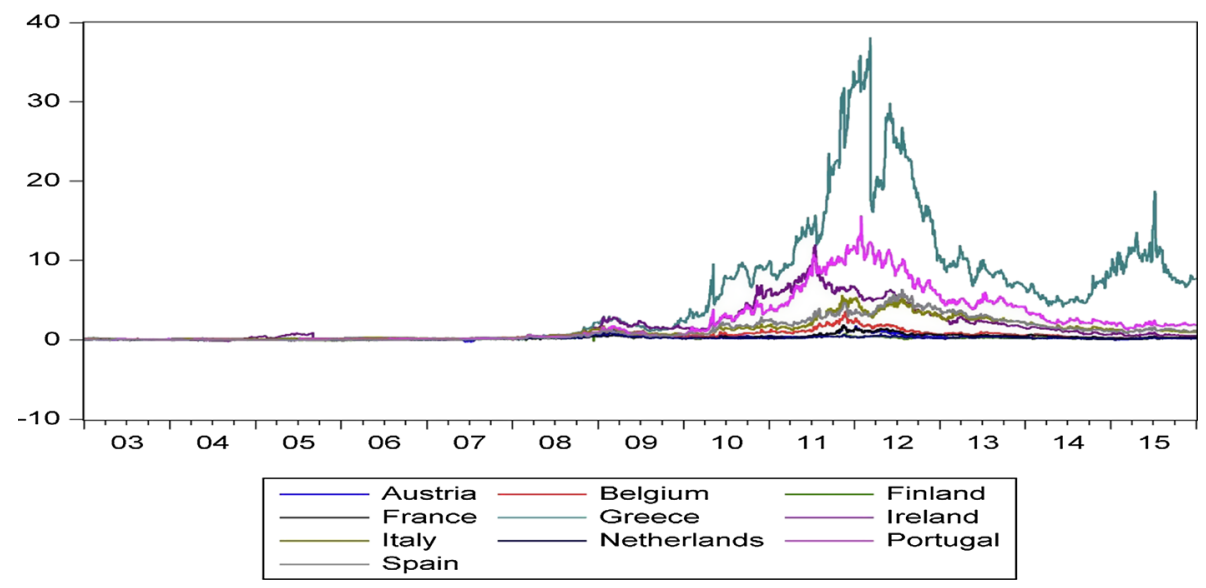

Fig. 1 Evolution of the daily 10-year sovereign debt yield spreads (\%). Source Datastream Thomson Reuters 
2018; Pentecost et al. 2019, among others), copula models (Wen et al. 2012; Aloui et al. 2013; Changqing et al. 2015, among others), wavelet transform (Dewandaru et al. 2016; Dash and Maitra 2019; Vácha et al. 2019, among others), network models (Zhu et al. 2018; Sensoy et al. 2019, among others), etc.

Regarding the crisis transmission mechanisms, the literature has classified them into two groups (Kaminsky and Reinhart 2000; Dungey and Gajurel 2014): On the one hand, the channels relating to fundamental-based contagion and on the other hand those linked to pure contagion. The fundamental contagion occurs when a crisis spreads from one country to another through their real and financial links or through common regional or global shocks (Calvo and Reinhart 1996; Kaminsky and Reinhart 2000; Dornbusch et al. 2000; Caramazza et al. 2004; Zhang et al. 2008; N'Diaye et al. 2010; Dewandaru et al. 2016, among others). This approach is based on the fundamental linkages/interdependence between economies that exist during non-crisis periods and transmit shocks during crisis ones. The pure contagion arises when a crisis spreads from one country to another due to investor behavior after taking into account their trade and financial ties, macroeconomic fundamentals and common shocks (Masson 1999; Calvo and Mendoza 2000; Kaminsky and Reinhart 2000; Dornbusch et al. 2000; Forbes and Rigobon 2002; Kodres and Pritsker 2002; Kumar and Persaud 2002; Bae et al. 2003; Sander and Kleimeier 2003; Dewandaru et al. 2016; Apergis et al. 2019, among others). In other words, pure contagion is detected by an excess of co-movements during crisis periods as a result of panics, herd instinct, an increase in risk aversion, a loss of confidence and sudden changes in market sentiment, etc.

In this study, we propose to analyze the transmission of the Greek crisis on the 10-year sovereign debt markets for a panel of EMU countries. To this end, we use the DCC model of Engle (2002) for a period ranging from January 01, 2003 to December 31, 2015. This methodology determines the volatility-adjusted co-movements of the spread series between Greece on the one hand (source of contagion) and the other countries on the other hand. Since our observation period also includes the subprime crisis, we analyze, albeit in a synthetic way, the contagion of this crisis on our DCC series. In this paper, we define contagion as a significant increase in heteroscedasticity-adjusted co-movements between markets following the occurrence of a crisis on one/a group of them (Forbes and Rigobon 2002).

It is interesting to note that the result of the shock transmission test depends on the definition of contagion, the data frequency, the length of stability and crisis periods and the econometric framework taken into account. Moreover, political responses to contagion effects differ considerably: from no response when contagion does not exist, to the establishment of structural reform and accommodating liquidity policies when contagion is dominant (Pericoli and Sbracia 2003; Dungey et al. 2011; Forbes 2012, among others).

There is a significant body of empirical literature testing for financial contagion of the Greek crisis on the EMU sovereign debt markets. We can divide these studies into two groups. On the one hand those which confirmed the contagion hypothesis of the Greek crisis and on the other hand those which rejected it. For example, Missio and Watzka (2011) used the DCC model of Engle (2002) to analyze the contagion effects of the Greek debt crisis in six EMU sovereign debt markets. The results showed the occurrence of contagion on the Belgian, Italian, Spanish and Portuguese sovereign markets in the summer of 2010. They also revealed the sensitivity of Spain and Portugal to the announcements of Greek rating cuts. De Santis (2012) found the same result based on the impulse response functions. Indeed, one unexpected notch downgrade on the Greek sovereign bond led to an accumulated increase in yield spreads after two months amounting respectively to about 40 basis points in Portugal, 25 basis points in Spain, 20 basis points in Ireland, 15 basis points in Italy, 7 basis points in Belgium and 3 basis points in France. 
Samitas and Tsakalos (2013) investigated the dependence structure between the Greek stock market on the one hand and those of seven EMU countries based on the ADCC model of Cappiello et al. (2006) and on Gaussian, Clayton and Joe-Clayton symmetric copulas on the other hand. The results revealed a statistically significant increase in co-movements between the Greek market and those of the other countries during the subprime crisis period. These links significantly declined during the Greek crisis, confirming a decoupling of these markets from Greek shocks. Moreover, to investigate financial contagion generated by the debt crisis in Greece, Philippas and Siriopoulos (2013) used a framework that contains two procedures, a spillover regime/switching model and a time-varying copula model. They found that contagion appetite exists across EMU bond markets based on excessive macroeconomic imbalances and risk perception/arbitrage appetites of international portfolios. Pragidis et al. (2015) used the heteroscedasticity-adjusted correlation model of Forbes and Rigobon (2002), the exponential generalized auto-regressive conditional heteroscedasticity (E-GARCH) model of Nelson (1991) extended for volatility spillovers and the corrected dynamic conditional correlation (cDCC) model of Aielli (2013) with an extension allowing for non-linearities in the unconditional correlation of the bond yield returns from June 2006 to July 2012. The results infirmed the contagion effects stemming from the 10-year Greek sovereign debt on six EMU sovereign bond markets. Moreover, they found a fragmentation between the sovereign markets of the core and peripheral countries, indicating that investors rely on economic fundamentals to assess the credit risk of each country.

Furthermore, using the univariate EGARCH model and the multivariate DCC-EGARCH model, Smeets (2016) investigated the contagion effects of the Greek crisis on six EMU sovereign bond markets from October 2009 to November 2012. The multivariate analysis revealed a generally decreasing co-movement between government bond returns. However, Smeets (2016) found the occurrence of a few temporary periods of "wake-up call" contagion in the Portuguese and Irish markets. Bird et al. (2017) analyzed the extent of contagion from the two Greek crises ${ }^{1}$ in six EMU 10-year sovereign debt markets. Using a rolling correlation model, a DCC-GARCH model and a $t$-copula model, they found that the transmission of shocks of the second crisis were at least as large as those associated with the first one. Recently and using the DCC model of Engle (2002), Kchaou and Bellalah (2020) examined the contagion effects of the Greek crisis in seven EMU sovereign bond markets. The results show the occurrence of the "wake-up call" contagion on the peripheral markets during the spring of 2010. With the exception of this period, the DCC series do not reveal any other contagious episodes, indicating the effectiveness of the measures taken by the ECB and the structural reforms imposed by the troika to Greece in stopping contagion.

The contribution of our work is twofold. First, and in order to investigate the transmission of the subprime and Greek crises, we calculated and plotted the upper and lower bounds of the confidence interval for each DCC series. To the best of our knowledge, this approach of Kchaou and Bellalah (2020) has never been used to study the contagion of the subprime and Greek crises between the 10-year sovereign bond yield spreads of the main EMU countries. Thus, this approach allows us to test for contagion at each time " $t$ " during the crisis period based directly on the correlation graphs. It also offers useful insights to policy makers to manage the contagion effect through the implementation of adequate measures. Second, we analyse whether the Greek title played the role of the global factor for the dynamics of each sovereign spread series during the observation period.

${ }^{1}$ Of 2009 and 2015. 
The rest of the paper is organized as follows. Section 2 presents the data and those descriptive statistics. Section 3 explains the econometric methodology. Section 4 discusses the empirical results. Section 5 concludes this study.

\section{Data and descriptive statistics}

We use the daily ${ }^{2} 10$-year sovereign bond spreads for ten major EMU countries, namely Austria, Belgium, Finland, France, Greece, Ireland, Italy, Portugal, Spain and the Netherlands. Thus, our sample includes core "Austria, Belgium, Finland, France and the Netherlands" and peripheral countries "Greece, Ireland, Italy, Portugal and Spain". Each spread series for each country in our sample is computed as the difference between its daily 10-year sovereign debt yields and those of the equivalent German bond. These yield series were extracted from Datastream Thomson Reuters from January 01, 2003 to December 31, 2015. The choice of a large number of observations (3392) avoids the inefficiency problem when a time-varying methodology such as DCC model is applied to small samples.

We started our observation period from January 2003 to have a long calm period and to avoid the shocks resulting from the dotcom and Argentinian crises as well as the accounting scandal. In addition, it ends on December 31, 2015 in order to avoid the adverse effects from Brexit, the presidential election of Trump, the trade war between the USA and China, the rise of populism in Europe and the Covid-19 crisis.

Tables 1 and 2 present descriptive statistics of the daily spread series in levels and in first differences, respectively. The means are not statistically different from zero basis point (bp) for all the spread series in first differences. Regarding the spread series in levels, the Finnish sovereign title records the lowest mean spread (18.12 bps) unlike the Greek sovereign bond which exhibits the highest mean spread, equal to 559.97 bps. The Greek debt has the largest volatility, unlike those of Finland and the Netherlands which show the lowest one for the series in levels. For the spread series in first differences, Greece still has the largest standard deviation, but only the Dutch sovereign debt remains the least volatile. The skewness and kurtosis statistics show that the spread series in levels and in first differences are not normally distributed. This result is confirmed by the Jarque-Bera test. Furthermore, the Ljung-Box and ARCH-LM tests for the two series (in levels and in first differences) show signs of autocorrelation and heteroscedasticity, respectively. Finally, the KPSS test rejects (accepts) the stationary hypothesis at the $1 \%$ level for the data in level (in first differences).

Table 3 presents the unconditional co-movement matrix between the spread series in levels during the observation period. It indicates strong positive co-movements between all the sovereign bond markets. The Spain-Italy pair exhibits the strongest linear correlation value, equal to 0.9701 . The Finland-Greece pair records the weakest one, equal to 0.4929 . The sharing of intense commercial and financial linkages boosted by the absence of exchange risk explains the importance of these values. Indeed, given the adoption of the single currency which strengthened the integration of EMU financial markets, the prices of their financial assets tend to be explained mostly by common factors so that a local market return would be determined by their covariances with other markets (Baele 2005; Bekaert et al. 2005, among others).

\footnotetext{
2 The choice of daily data is motivated by the fact that extreme co-movements between financial markets are more likely to occur at high frequencies. In addition, daily data contain richer information than other data frequencies (Bannigidadmath \& Narayan 2016; Kenourgios et al. 2016).
} 


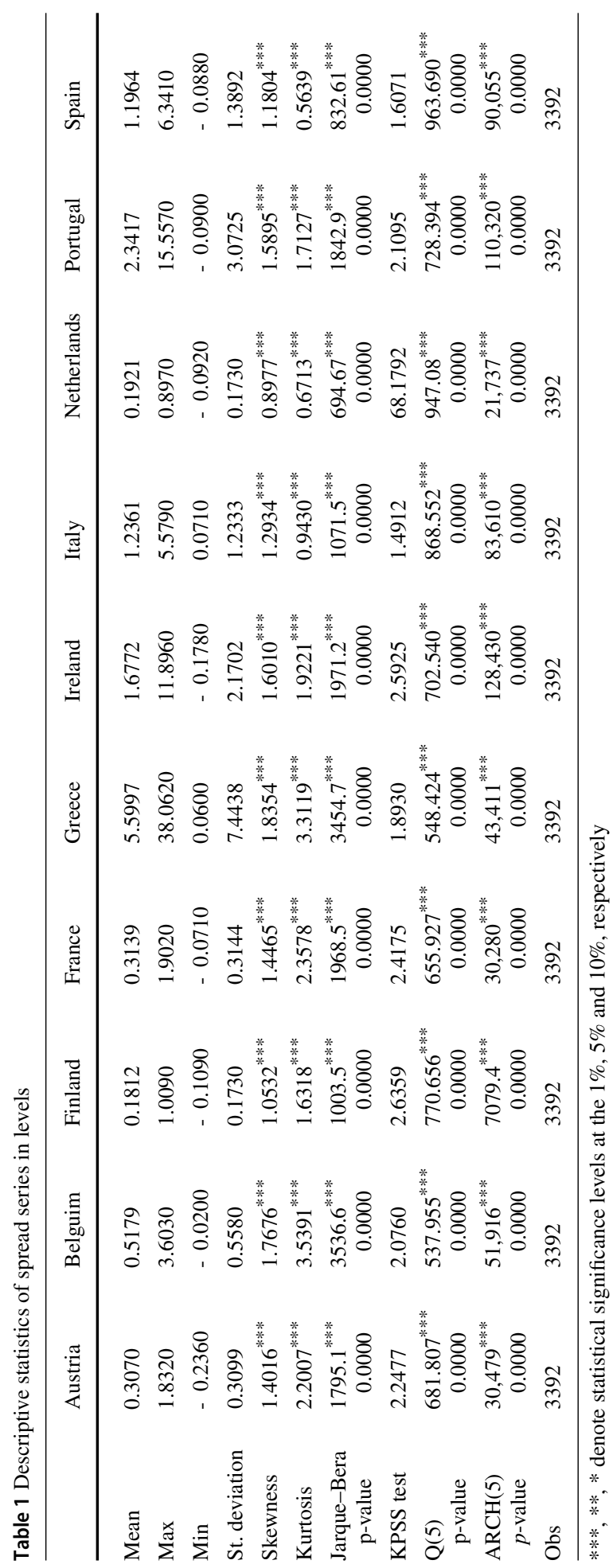




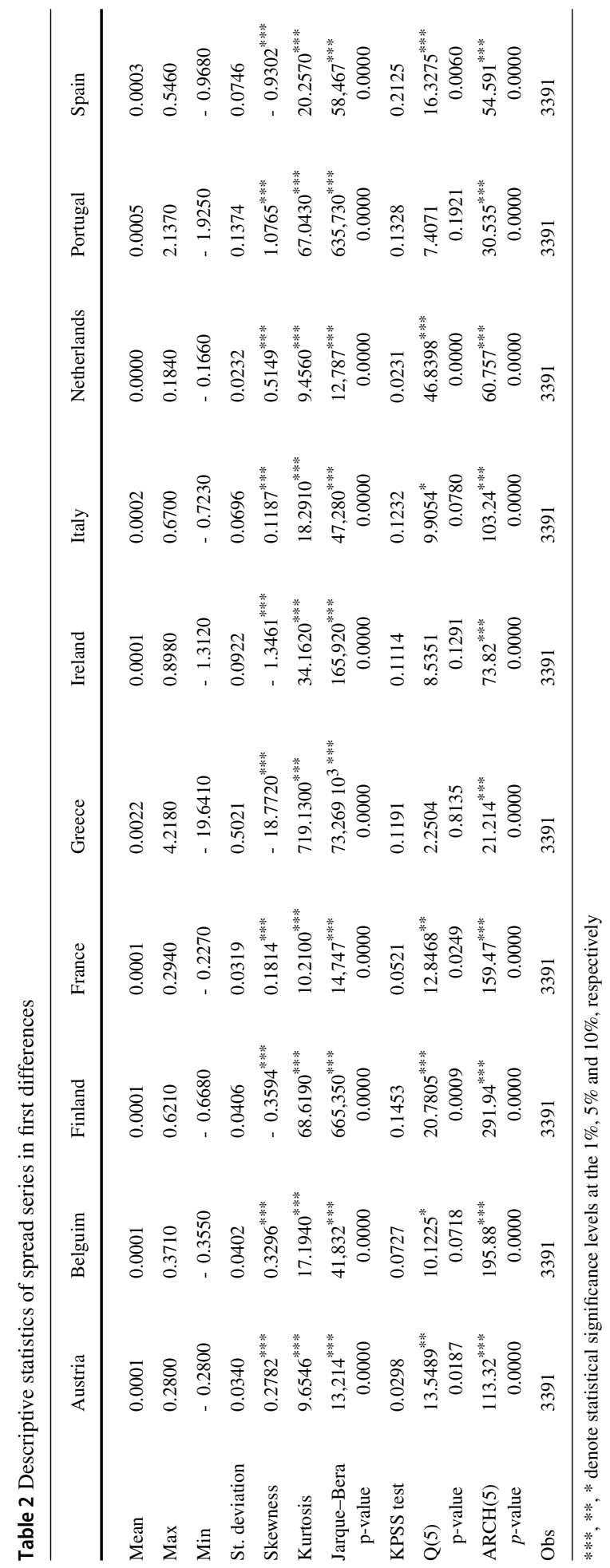




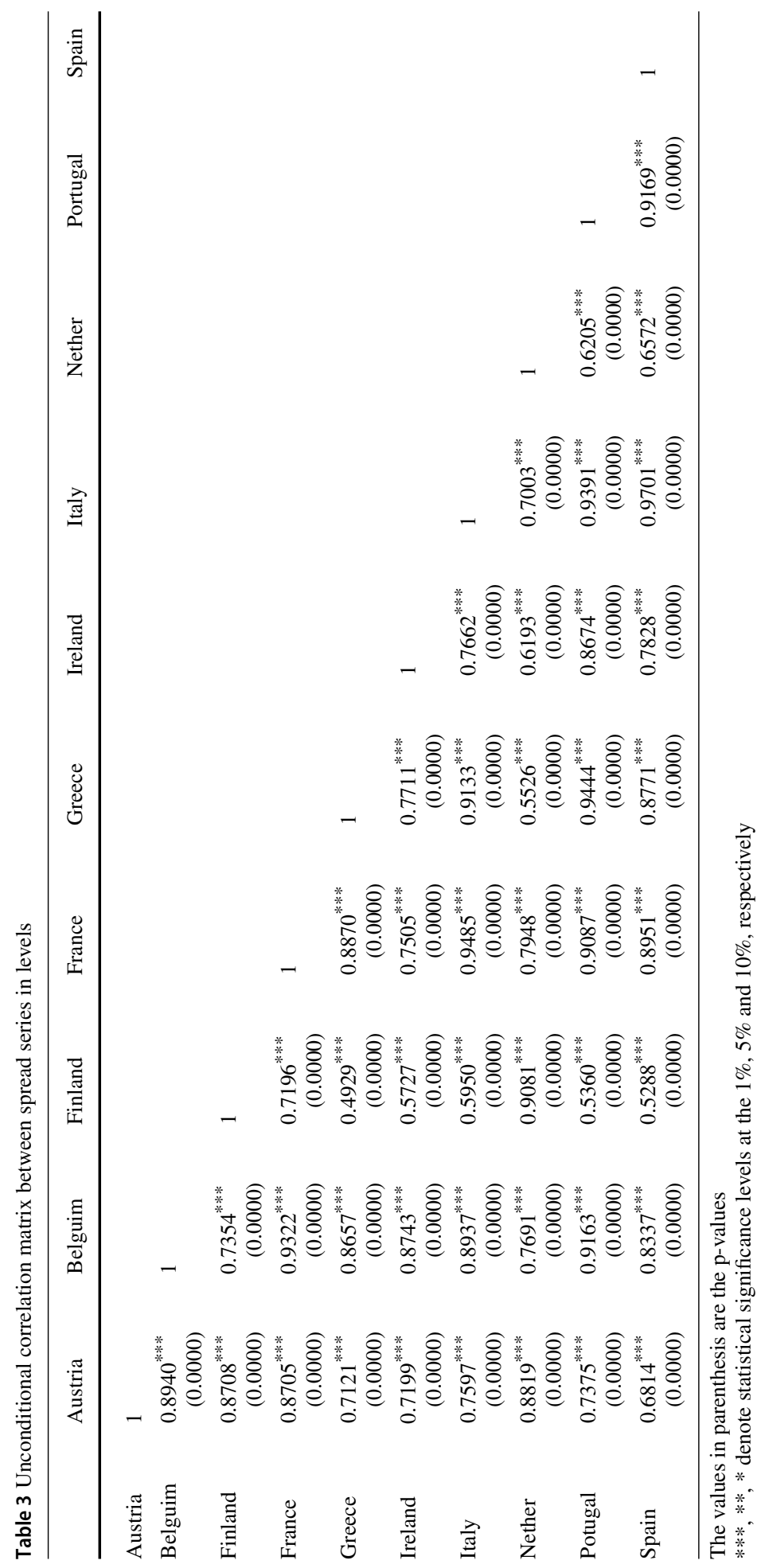




\section{Empirical framework}

We rely on the DCC model of Engle (2002) which has been widely used in finance to examine dynamic conditional co-movement between financial asset prices/returns. It is a generalization of the constant conditional correlations (CCC) model of Bollerslev (1990). It has several advantages. First, it takes into account the heteroscedasticity bias. Second, it is parsimonious. Third, it allows additional exogenous variables to be included in the conditional mean and variance equations. Fourth and finally, it is useful in the analysis of contagion through the modeling of dynamic correlations.

In our study, the multivariate GARCH-DCC model is applied to sovereign debt spreads between Greece and the other nine markets. The conditional mean equation takes the following form:

$$
\begin{aligned}
& \Delta s_{i, t}=\gamma_{0}+\gamma_{1} M A(1)+\gamma_{2} \Delta s_{\text {Greece }, t-1}+\varepsilon_{i, t} \\
& \varepsilon_{i, t} \sim \operatorname{skewed}-t\left(\varepsilon_{i, t} \mid \tau_{i}, \varphi_{i}\right)
\end{aligned}
$$

where $\gamma_{0}$ is a constant term, $s_{i, t}$ is the sovereign bond spread of country " $\mathrm{i}$ " at day " $\mathrm{t}$ ", $\Delta$ is the first difference operator, $\Delta s_{i, t}=\left[\Delta s_{1, t}, \ldots, \Delta s_{n, t}\right]^{\prime}$ is $n \times 1$ vector including each spread series in first differences and $\varepsilon_{i, t}=\left[\varepsilon_{1, t}, \ldots, \varepsilon_{n, t}\right]^{\prime}$ is the $n \times 1$ vector of innovations conditional on the information set at time $t-1$.

The error term is assumed to follow a conditionally multivariate skewed-t distribution. The skewed-t density is an extension of the Gaussian and Student densities (Hansen 1994). So, it takes into account both skewness and excess kurtosis (Arnold and Beaver 2000; Gupta 2003).

The density function of the skewed-t distribution is given by:

$$
\varepsilon \sim \text { skewed }-t(\varepsilon \mid \tau, \varphi)= \begin{cases}\left\{b c\left(1+\frac{1}{\tau-2}\left(\frac{b \varepsilon+a}{1-\varphi}\right)^{2}\right)^{-\tau+1 / 2}\right. & \text { if } \varepsilon<-\frac{a}{b} \\ b c\left(1+\frac{1}{\tau-2}\left(\frac{b \varepsilon+a}{1-\varphi}\right)^{2}\right)^{-\tau+1 / 2} & \text { if } \varepsilon \geq-\frac{a}{b}\end{cases}
$$

The values of $a, b$ and $c$ are defined as follows:

$$
\begin{gathered}
a \equiv 4 \varphi c \frac{\tau-2}{\tau-1} \\
b \equiv 1+3 \varphi^{2}-a^{2} \\
c \equiv \frac{\Gamma(\tau+1 / 2)}{\sqrt{\pi(\tau-2)} \Gamma(\tau / 2)}
\end{gathered}
$$

where $\tau$ is the kurtosis parameter $(2<\tau<\infty)$ and $\varphi$ is the asymmetry parameter $(-1<$ $\varphi<1)$.

The lagged Greek sovereign bond spread is used as an exogenous variable in each conditional mean equation to account for a global factor. It constituted the AR(1) term in the conditional mean equation for Greece.

The variance-covariance matrix is specified as:

$$
H_{t}=E\left[\varepsilon_{t}, \varepsilon_{t}^{\prime}\right]=D_{t} R_{t} D_{t}
$$

where $R_{t}$ is the time-varying conditional correlation matrix and $D_{t}$ is the diagonal matrix of the time-varying standard deviations from univariate GARCH models with $\sqrt{h_{i i, t}}$ on the $i$ th 
diagonal. The elements in $D_{t}$ follow the univariate GARCH process introduced by Bollerslev (1986), which takes the following form:

$$
h_{i, t}=w+\alpha \varepsilon_{i, t-1}^{2}+\beta h_{i, t-1}
$$

where $w$ is a constant term, $\alpha$ measures the ARCH effect and $\beta$ captures the GARCH effect.

The DCC model requires two steps in order to estimate the conditional covariance matrix $H_{t}$. In a first step, univariate GARCH models are fitted for each spread series and estimates of $\sqrt{h_{i i, t}}$ are obtained. In a second step, the standardized residuals $z_{t}\left(w i t h: z_{i, t}=\varepsilon_{i, t} / h_{i i, t}^{\frac{1}{2}}\right)$ are used to determine the DCC series.

The evolution of the correlation in the DCC model is given by:

$$
Q_{t}=(1-a-b) \bar{Q}+a z_{t-1} z_{t-1}^{\prime}+b Q_{t-1}
$$

where $Q_{t}$ is the time-varying covariance matrix of standardized residuals, $\bar{Q}=E\left[z_{t} z_{t}^{\prime}\right]$ is the unconditional covariance matrix of standardized residuals and $a$ and $b$ are not negative scalar parameters satisfying $a+b<1$.

The time-varying correlation matrix $R_{t}$ is given by:

$$
R_{t}=Q_{t}^{*-1} Q_{t} Q_{t}^{*-1}
$$

where $Q_{t}^{*}$ is a diagonal matrix containing the square root of the elements of the main diagonal of $Q_{t}$.

Note that the DCC model is estimated by the quasi-maximum likelihood.

\section{Empirical analysis}

\subsection{The MA(1)-GARCH(1,1)-DCC estimation}

Table 4 (Panel A) presents the results of the estimation of the univariate MA(1)-GARCH(1,1) model for each spread series. The MA(1) terms for all of the conditional mean equations are statistically significant, supporting the selection of the MA(1) process. Moreover, all the $\gamma_{2}$ coefficients are positive and statistically significant except the Finnish, Irish, Spanish and Greek cases. Thus, during the period under study, the Greek sovereign spread played the role of the global factor for the majority of the EMU sovereign bond markets. In other words, the spread of their sovereign debts at day " $\mathrm{t}$ " is determined, among others, by that of the Greek one at day "t-1". However, the impact of this mean transmission is negligible given the low values of $\gamma_{2}$. In addition, the values of $\gamma_{2}$ were less important for the core Eurozone countries compared to those of periphery ones. This indicates a higher sensitivity of the sovereign markets of the latter compared to those of the former regarding the level of the Greek risk premium. For each conditional variance equation, the $\alpha$ and $\beta$ parameters are significant and their sum is close to unity, suggesting a high persistence of the conditional volatility. Furthermore, the estimated asymmetry $\varphi$ and kurtosis $\tau$ parameters are statistically significant for all the spread series which justifies the choice of the skewed-t distribution.

The estimation results of the multivariate DCC model are reported in Table 4 (Panel B). The estimated $a$ and $b$ terms are positive and statistically significant. In addition, their sum is close to unity revealing a strong persistence of DCC. All these results justify the use of the MA(1)-GARCH(1,1)-DCC model and show that the estimated DCC series can provide a reasonable inference about the evolution of co-movements over time. 


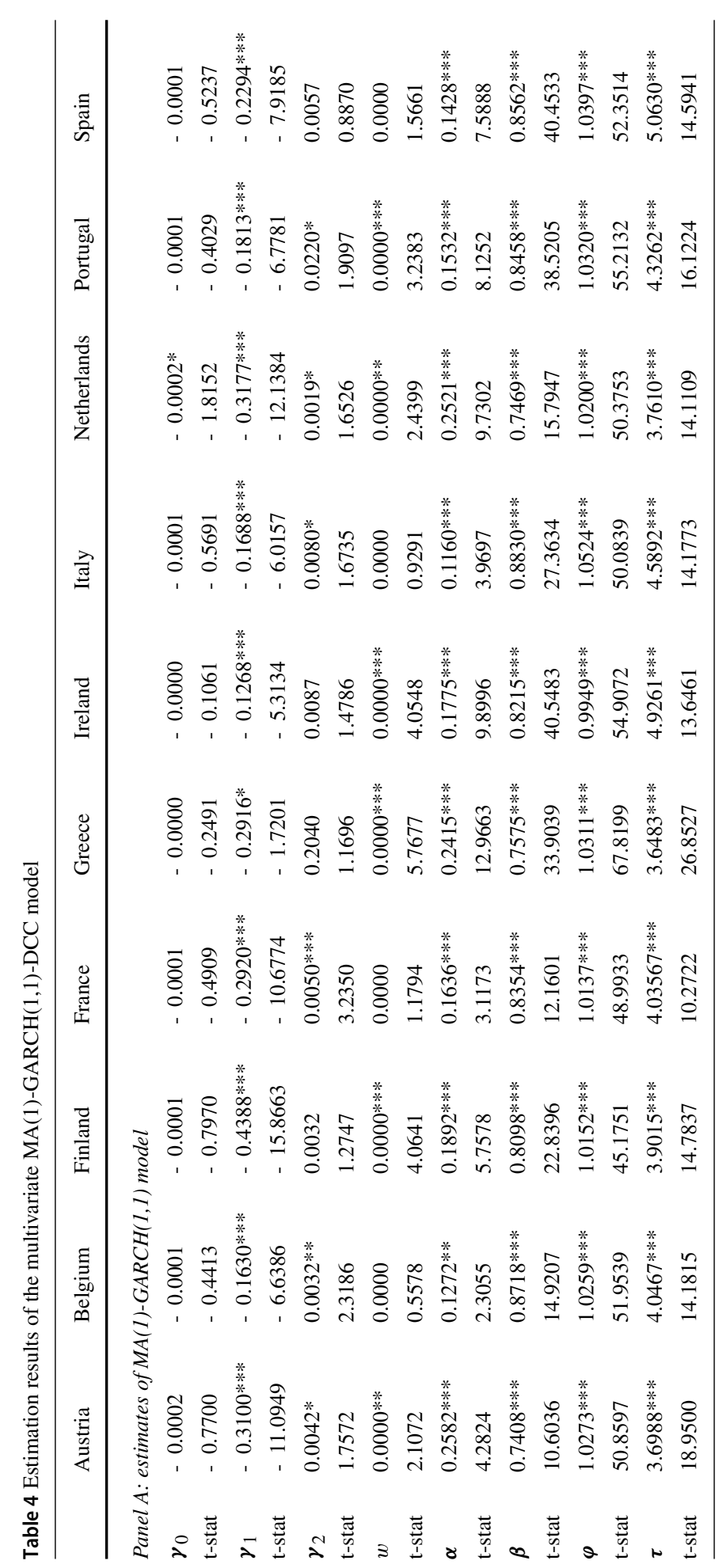




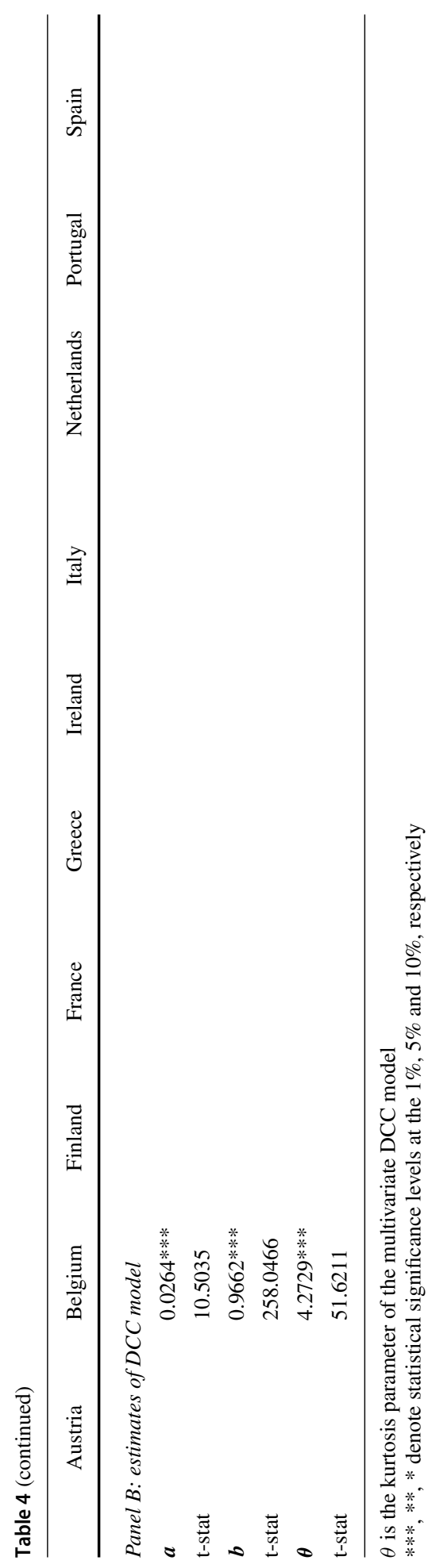




\subsection{The statistical analysis of DCC behavior}

Table 5 provides the descriptive statistics of DCC series. It shows that the peripheral countries (except Ireland) present on average the highest conditional correlations with Greece, reflecting the similarities in their macroeconomic fundamentals. The Greece-Spain pair records the strongest mean correlation, equal to 0.5181 , unlike the Greece-Finland couple which presents the weakest average co-movement, equal to 0.1787 . The Greece-France pair presents the highest volatility $(0.1973)$ followed by the Greece-Netherlands couple (0.1943). DCC series between Greece and Finland shows the lowest volatility, equal to 0.1257 .

To examine the contagion effect of the Greek debt crisis in the nine sovereign bond markets in our sample, we calculated and plotted the confidence interval for each DCC series as shown in Fig. 2. ${ }^{3}$ Therefore, we interpret an (a) increase (fall) of DCC series beyond (below) the upper (lower) bound of the calculated confidence interval as a significant increase (decrease). We proceed in this manner, inspired by the work of Kchaou and Bellalah (2020), to draw robust conclusions about the existence/absence of contagion during crisis period directly through the analysis of the dynamics of DCC graphs. Given that the investigation of contagion requires the determination of the crisis period, the literature shows the use of two methods. The first one is economic/ad-hoc based on the major economic and financial events published by official sources (Forbes and Rigobon 2002; Chiang et al. 2007). The second one is statistical that defines the crisis length endogenously using the SETAR models of Teräsvirta (1994), the structural break tests (Tamakoshi and Hamori 2014) and the Markov Switching Models (Boyer et al. 2006; Rodriguez 2007). After this step, the contagion test is based on the statistical analysis of co-movement behavior between the prices of financial assets during the crisis period which could be very long. Thereby, the test of contagion at each time " $t$ " of the crisis period constitutes the advantage of the approach of Kchaou and Bellalah (2020) compared to other methods, suggesting its precision and its relevance in empirical works relating to the transmission of shocks. Indeed, several studies have shown that the transmission of shocks in the financial markets disappears after seven days or less (Baig and Goldfajn 1999; Gallegati 2012; Ait-Sahalia et al. 2015). For policy makers, this approach offers them useful insights for reacting timely to address the contagion effect through the implementation of adequate measures.

Since the observation period includes the subprime crisis, we analyze, in a synthetic way, the impact of its shocks on DCC behavior. The Federal Reserve of Saint-Louis (FED 2009) and the Bank for International Settlements (BIS, 2009) divided the subprime crisis period into three phases. Phase 1, started on August 1, 2007 and ended on September 15, 2008, is described as "the initial financial crisis". Phase 2, spanning from September 16, 2008 to December 31, 2008, is characterized by a "sharp deterioration in the financial markets". Phase 3 covers January 1, 2009 to March 31, 2009, and is termed the "macroeconomic deterioration". Therefore, the subprime crisis is set from August 01, 2007 to March 31, 2009.

The analysis of Fig. 2 reveals a persistent upward trend for the majority of DCC on the precrisis period (especially between 2004 and 2007). This reflects a strengthening of convergence

\footnotetext{
3 To determine the values of the upper and lower bounds of the confidence interval for each series of correlations, we applied the following formulas:

value of the upper bound of $D C C_{G r, i}=$ mean value of $D C C_{G r, i}+1.96 \times$ standard deviation DCC $C_{G r, i}$

value of the lower bound of $D C C_{G r, i}=$ mean value of $D C C_{G r, i}-1.96 \times$ standard deviation DCC $C_{G r, i}$
} 


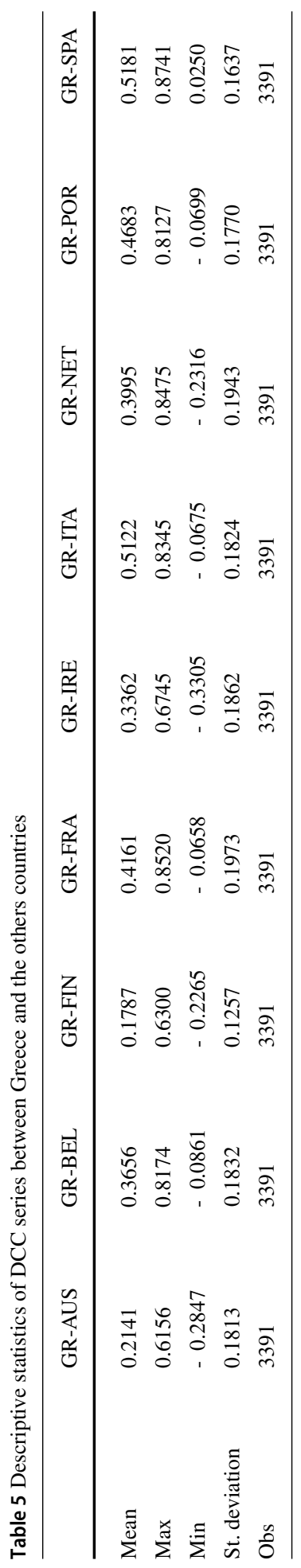



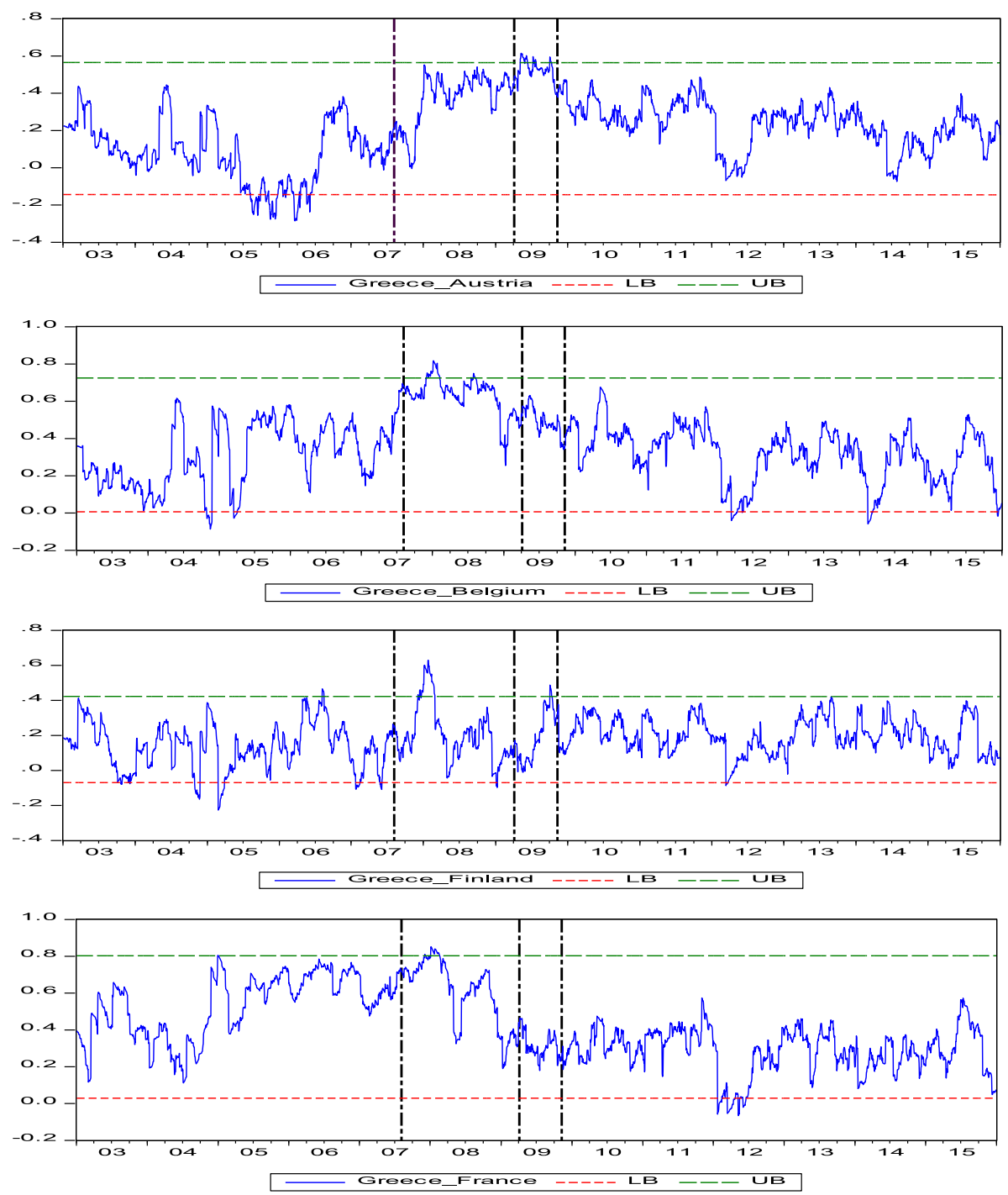

Fig. 2 Evolution of DCC series between Greece and the others countries of the sample. Notes For each plot, UB and LB denote the upper and lower bounds of the confidence interval, respectively. For each plot, the right dotted vertical line denotes the onset of the Greek crisis; the remaining dotted vertical lines delimit the subprime crisis

on EMU sovereign debt markets. This result is consistent with those by Ehrmann et al. (2011), Arghyrou and Kontonikas (2012) and Sensoy et al. (2019). Therefore, it turns out that the behavior of EMU sovereign spreads is influenced by regional rather than idiosyncratic risk factors before the subprime crisis.

Besides, Fig. 2 shows that the contagion of the subprime crisis impacted five market pairs, namely Greece-Belgium, Greece-Finland, Greece-France, Greece-Netherlands and GreeceSpain. These findings are in line with those of Samitas and Tsakalos (2013), Tamakoshi 

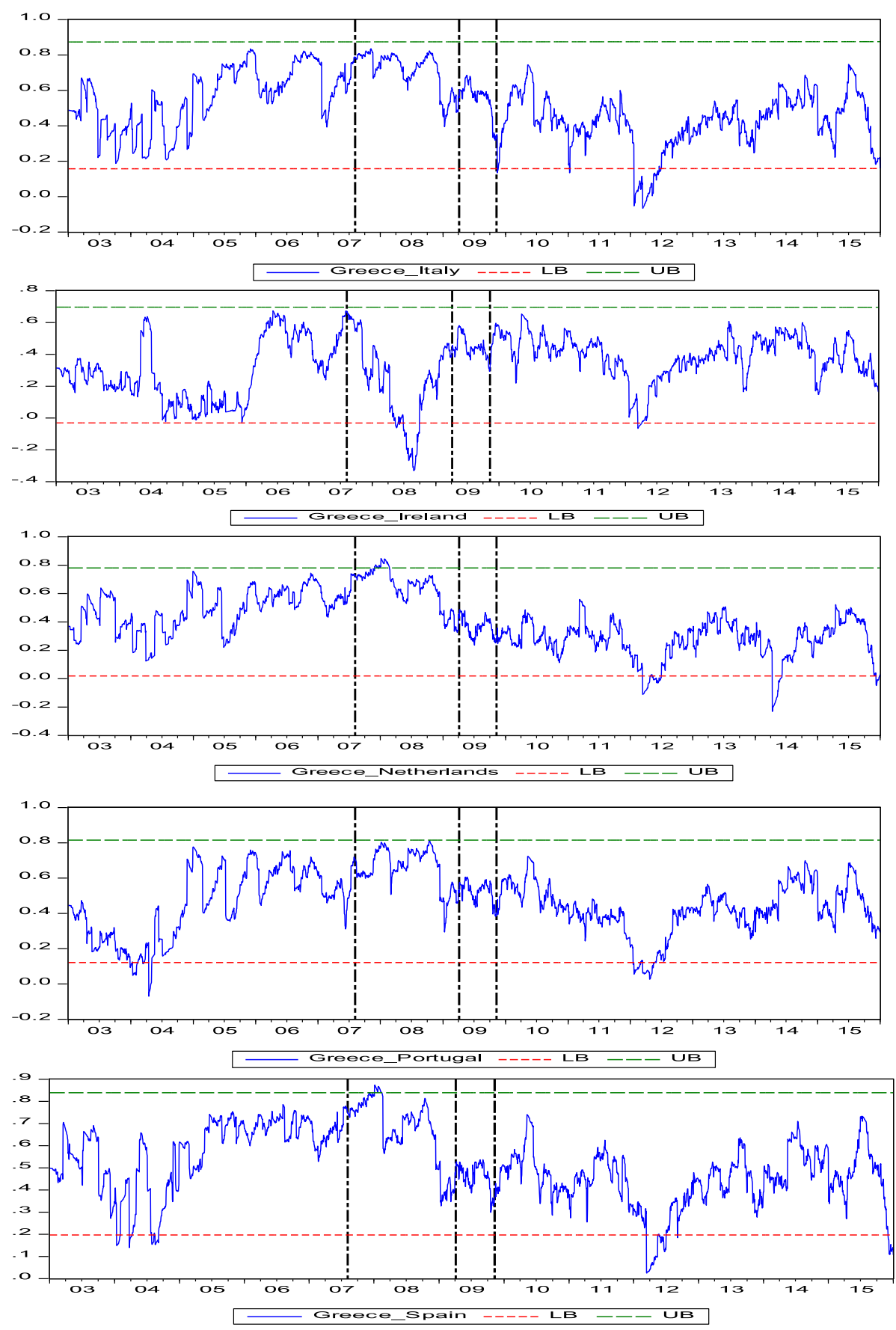

Fig. 2 continued 
and Hamori (2013) and Leschinski and Bertram (2017) who used several techniques such as copula, DCC, ADCC and the canonical contagion models. These empirical works highlighted the transmission of shocks of the subprime crisis in the EMU financial markets. In addition, our results show that the majority of contagious episodes occurred at the end of 2007 and at the beginning of 2008, thus during the first phase of the subprime crisis defined by official sources (BIS, 2009; FED, 2009). This reflects a strong integration of the EMU markets into the global financial markets. Thus, they were affected by the shocks of the subprime crisis before the major event of the bankruptcy of Lehman Brothers. The number of contagious episodes as well as their durations changed from one pair to another, indicating the heterogeneity of the impact of the subprime crisis on the sovereign markets in our sample. This finding rejects the hypothesis of a perfect integration of the EMU sovereign debt markets, confirming the study of Pappas et al. (2016). Using an ADCC-GARCH framework and a Markov-Switching model, these authors found the same result in European stock markets during the subprime crisis. Therefore, Pappas et al. (2016) concluded that one-size fits all policies are likely to be ineffective.

The European sovereign debt crisis (ESDC) was divided into three phases by Kenourgios (2014) based on timelines from the ECB and Reuters. Phase 1 starts on the 5th of November 2009 and ends on the 22nd of April 2010, including the Greek budget deficit announcement of Papandreou's government. Phase 2 goes from the 23rd of April 2010 to the 14th of July 2011. It begins when the Greek government requested a rescue plan from the Troika on April 23, 2010 and a few days before its ratification on May 2nd, 2010. Phase 3 (15 July 2011 onward) begins just after the publication of the banking stress tests and when other European countries announced austerity measures. Given that the Greek crisis triggered the ESDC, we set the Hellenic crisis period from November 05, 2009 (the start date of Phase 1 of the ESDC) to the end of the period under study (December 31, 2015).

The analysis of the DCC between Greece and the other countries rejects the presence of contagious episodes. It shows that the Greek crisis was an isolated case on the EMU sovereign debt markets, confirming the results of Pragidis et al. (2015). It is interesting to note that these authors employed the adjusted correlation coefficient of Forbes and Rigobon (2002), an EGARCH model extended for volatility spillovers and an extension of the cDCC model. Similarly, this finding is in line with that of Samitas and Tsakalos (2013). Using the ADCC model and copula functions, Samitas and Tsakalos (2013) accepted the no contagion hypothesis in seven EMU stock markets during the Greek crisis.

Besides, our finding contradicts those of Missio and Watzka (2011), De Santis (2012), Cronin et al. (2016), Bird et al. (2017), Georgoutsos and Migiakis (2017), Pentecost et al. (2019) and Kchaou and Bellalah (2020) who confirmed the existence of contagion effect within the euro area. It demonstrates either the insensitivity of investors to bad Greek economic and financial news ${ }^{4}$ or the effectiveness of the measures implemented by the ECB and EU policymakers which cushioned the shocks of the Greek sovereign bond market. Indeed, three rescue plans were adopted in favor of Greece in 2010, 2012 and 2015 which enabled it to avoid a Grexit. In addition, a European Financial Stability Facility (EFSF) was set up in May 2010 and was replaced in October 2012 by the European Stability Mechanism (ESM) to safeguard financial stability in the euro area. This is done by providing loans to countries facing/threatened by refinancing difficulties, such as Greece in 2012 and 2015. Moreover, the ECB conducted sovereign and private debt purchases on secondary bond markets under the Securities Markets Program (SMP) since May 2010, which was replaced by the Outright

4 This could be explained by the weakness of its weight in the Eurozone. Indeed, the Greek GDP represents $2.89 \%$ of the EMU GDP in 2009 (OECD). Moreover, the Greek public debt corresponds to $4.05 \%$ of the Euro zone public debt for the same year (Eurostat). 
Monetary Transactions (OMT) in September 2012. Through the OMT program which has never been activated, the ECB has signaled that it will act "under certain conditions" as a lender of last resort for sovereign issuers in the Eurozone (Saka et al. 2015). This program aimed to lower the redenomination risk linked to fears of a possible break-up of the euro area (Neri and Ropele, 2015). Gödl and Kleinert (2016) highlighted the effectiveness of the ECB's unconventional monetary policy (SMP, the two 3-year longer-term refinancing operations "LTROs" and OMT) and of the Greek debt restructuring operation in March 2012 in lowering sovereign spreads of the Hellenic economy. Krishnamurthy et al. (2018) found that the SMP and OMT programs have been successful in reducing market segmentation, redenomination risk and default risk in stressful countries, while also leading to positive macroeconomic spillovers to the rest of the Eurozone. Several other studies have shown the effectiveness of these measures in reducing the spreads or yields of sovereign debts of peripheral countries (De Pooter et al. 2012; Schwaab and Eser 2013; Altavilla et al. 2014; Falagiarda and Reitz 2015; Szczerbowicz 2015; Ghysels et al. 2017, among others).

Furthermore, during the violent phases of the Greek debt crisis, all DCC series showed a downward trend. These episodes occurred between the end of 2009 and March 2012 and during the summer of 2015. This result reveals a disintegration of the Greek debt market with those of other Eurozone countries during times of great uncertainty, confirming the results of Ehrmann and Fratzscher (2017) and Caporin et al. (2018). These latter highlighted the fragmentation of the EMU sovereign bond markets during the ESDC (and therefore during the Greek crisis). Between 2009, quarter 4, and 2012, quarter 2, Smeets (2016) observed the same result for DCC between the 10-year Greek sovereign debt returns and those of Austria, Germany, Portugal, Ireland, Italy and Spain. However, contrary to his results, we did not identify short periods of time during which the generally decreasing tend is interrupted by significant increases of correlation coefficients, interpreted as the occurrence of contagion. By conducting a Wavelet Coherence analysis, Vácha et al. (2019) found the same result as that of Smeets (2016) except that the decline in co-movements between the Greek sovereign market and those of other countries has began since the bankruptcy of Lehman Brothers.

Consequently, the rise of the sovereign debt spreads of the countries in our sample is not due to contagion effects stemming from the Greek crisis. This phenomenon only reflects the deterioration of their sovereign credit risks. Therefore, unlike the period 2004-2007, the pricing of sovereign debts in the Eurozone during the Greek crisis period is carried out on a case-by-case basis depending on the macroeconomic fundamentals, the level of competitiveness and the degree of economic robustness of each country. Our interpretation is in line with that of Pragidis et al. (2015). It also indicates ex-post the need for austerity and budgetary consolidation measures imposed on Greece by the troïka to find sustainable refinancing rates and guarantee a successful return in the EMU sovereign debt markets. Finally, the results show that international diversification benefits are still possible in the ten sovereign markets in our sample during the Greek crisis. This finding contradicts that by Celik (2012) who highlighted the decline in the benefits of international diversification during periods of financial turmoil. She found the contagion evidence during the subprime crisis for most of the foreign exchange markets of several emerging and developed countries. Consequently, she concluded that the gain from international diversification by holding a portfolio consisting of diverse foreign markets decreases due to high correlation coefficients during crisis periods. In our study, the results show that co-movements between financial assets do not increase significantly in all markets and during all crisis periods. Therefore, exploiting the potential of international diversification is still possible in the financial markets even in times of crisis. 


\section{Conclusion}

We investigate the contagion effects of the Greek crisis on nine EMU sovereign bond markets. Following this purpose, we employ a DCC model of Engle (2002) to determine the heteroscedasticity-adjusted correlations between Greece and each of these countries from January 01st, 2003 to December 31st, 2015. Inspired by the work of Kchaou and Bellalah (2020), we calculated and plotted the confidence interval for each DCC series. As indicated previously, this approach allows us to test for contagion directly through the analysis of the dynamics of DCC graphs. We also test whether the Greek sovereign debt played the role of a global factor in the EMU sovereign bond markets.

Summarizing the empirical findings, we infirm the contagion hypothesis stemming from the Greek debt crisis in all the sovereign bond markets in our sample. Thus, the Greek crisis was an isolated case in the Eurozone sovereign debt markets. We justify this result either by the weakness of its economic weight within the EMU or by the effectiveness of the measures implemented by the troika and the governments of the euro area countries in addressing contagion risk. Consequently, the increase in the 10-year sovereign debt spreads of euro area countries and mainly those of periphery ones only indicates the deterioration of their macroeconomic fundamentals. These results are in line with those of Pragidis et al. (2015). They go against those by Missio and Watzka (2011), De Santis (2012), Cronin et al. (2016), Bird et al. (2017), Georgoutsos and Migiakis (2017), Pentecost et al. (2019), Kchaou and Bellalah (2020), etc. Moreover, DCC series reveal a downward dynamic during the acute phases of the Greek crisis, suggesting the disintegration of the Hellenic debt market with those of other euro area countries during the periods of financial turmoil. This fact is in line with those of Ehrmann and Fratzscher (2017) and Caporin et al. (2018). Besides, we find that the Greek spread was a global factor for the majority of the countries in our sample. However, its overall impact is very low, which could also explain the non-contagious nature of the Hellenic crisis. Furthermore, most of these markets were impacted by the adverse effects of the subprime crisis, indicating the importance of its shock wave. ${ }^{5}$ It also reveals a strong integration of the EMU markets into the global financial markets. Finally, we show a persistent upward trend for the majority of DCC especially between 2004 and 2007, suggesting an increase of market integration between EMU countries. On the one hand, this fact increases their vulnerability to external shocks and could explain, among others, their exposure to the contagion of the subprime crisis. On the other hand, the increase in the convergence of sovereign debt spreads ensured a better transmission of the common monetary policy in the Eurozone during the pre-crisis period, unlike the Greek crisis period when the peripheral countries suffered from a credit crunch.

All these results provide valuable information for policymakers and central bankers in understanding the evolution of the Greek crisis and for financial market participants who aim to maximize their gains from international diversification.

The application of the approach of Kchaou and Bellalah (2020) coupled with an asymmetric GARCH and DCC models to European domestic sector indices during the euro crisis and to regional stock market indices in the context of the current Covid-19 crisis constitutes a future avenue of research.

\footnotetext{
5 Using cointegration tests, vector error correction model and the asymmetric generalized DCC model, Kenourgios and Padhi (2012) show that several emerging stock and bond markets from various regions around the world were affected by the transmission of the subprime crisis.
} 


\section{References}

Abad, P., Chuliá, H., \& Gómez-Puig, M. (2010). EMU and European government bond market integration. Journal of Banking and Finance, 34(12), 2851-2860. https://doi.org/10.1016/j.jbankfin.2009.10.009.

Aielli, G. P. (2013). Dynamic conditional correlation: On properties and estimation. Journal of Business and Economic Statistics, 31(3), 282-299. https://doi.org/10.1080/07350015.2013.771027.

Aït-Sahalia, Y., Cacho-Diaz, J., \& Laeven, R. J. A. (2015). Modeling financial contagion using mutually exciting jump processes. Journal of Financial Economics, 117(3), 585-606. https://doi.org/10.1016/j.jfineco. 2015.03.002.

Alexakis, C., \& Pappas, V. (2018). Sectoral dynamics of financial contagion in Europe - The cases of the recent crises episodes. Economic Modelling, 73, 222-239. https://doi.org/10.1016/j.econmod.2018.03.018. Aloui, R., Hammoudeh, S., \& Nguyen, D. K. (2013). A time-varying copula approach to oil and stock market dependence: The case of transition economies. Energy Economics, 39, 208-221. https://doi.org/10.1016/j. eneco.2013.04.012

Altavilla, C., Giannone, D., \& Lenza, M. (2014). The financial and macroeconomic effects of OMT announcements. http://www.ecb.europa.euhttp://ssrn.com/abstract_id=2464118http://www.ecb.europa.eu/ $\mathrm{pub} / \mathrm{scientific/wps/date/html/index.en.html.}$

Apergis, N., Christou, C., \& Kynigakis, I. (2019). Contagion across US and European financial markets: Evidence from the CDS markets. Journal of International Money and Finance, 96, 1-12. shttps://doi.org/ https://doi.org/10.1016/j.jimonfin.2019.04.006

Arghyrou, M. G., \& Kontonikas, A. (2012). The EMU sovereign-debt crisis: Fundamentals, expectations and contagion. Journal of International Financial Markets, Institutions and Money, 22(4), 658-677. https:// doi.org/10.1016/j.intfin.2012.03.003.

Arnold, B. C., \& Beaver, R. J. (2000). Some skewed multivariate distributions. American Journal of Mathematical and Management Sciences, 20(1-2), 27-38. https://doi.org/10.1080/01966324.2000.10737499.

Bae, K. H., Karolyi, G. A., \& Stulz, R. M. (2003). A new approach to measuring financial contagion. Review of Financial Studies, 16(3), 717-763. https://doi.org/10.1093/rfs/hhg012.

Baele, L. (2005). Volatility spillover effects in European equity markets. Journal of Financial and Quantitative Analysis, 40(2), 373-401. https://doi.org/10.1017/s0022109000002350.

Baig, T., \& Goldfajn, I. (1999). Financial market contagion in the Asian crisis. IMF Staff Papers 1999 46:2, 46(2), 167-195. https://doi.org/https://doi.org/10.2307/3867666

Bannigidadmath, D., \& Narayan, P. K. (2016). Stock return predictability and determinants of predictability and profits. Emerging Markets Review, 26, 153-173. https://doi.org/10.1016/j.ememar.2015.12.003.

Bekaert, G., Harvey, C. R., \& Ng, A. (2005). Market integration and contagion. Journal of Business, 78(1), 39-69. https://doi.org/10.1086/426519.

Bird, G., Du, W., Pentecost, E., \& Willett, T. (2017). Was it different the second time? An empirical analysis of contagion during the crises in Greece 2009-15. The World Economy, 40(12), 2530-2542. https://doi.org/ $10.1111 /$ twec. 12553 .

BIS (2009). The international financial crisis: Timeline, impact and policy responses in Asia and the Pacific. Bank for International Settlements.

Bollerslev, T. (1986). Generalized autoregressive conditional heteroskedasticity. Journal of Econometrics, 31(3), 307-327. https://doi.org/10.1016/0304-4076(86)90063-1.

Bollerslev, T. (1990). Modelling the Coherence in Short-Run Nominal Exchange Rates: A Multivariate Generalized Arch Model. The Review of Economics and Statistics, 72(3), 498. https://doi.org/10.2307/2109358. Boyer, B. H., Kumagai, T., \& Yuan, K. (2006). How do crises spread? Evidence from accessible and inaccessible stock indices. Journal of Finance, 61(2), 957-1003. https://doi.org/10.1111/j.1540-6261.2006.00860.x. Calvo, G. A., \& Mendoza, E. G. (2000). Rational contagion and the globalization of securities markets. Journal of International Economics, 51(1), 79-113. https://doi.org/10.1016/S0022-1996(99)00038-0.

Calvo, S., \& Reinhart, C. (1996). Capital flows to Latin America : Is there evidence of contagion effects? Policy Research Working Paper Series.

Caporin, M., Pelizzon, L., Ravazzolo, F., \& Rigobon, R. (2018). Measuring sovereign contagion in Europe. Journal of Financial Stability, 34, 150-181. https://doi.org/10.1016/j.jfs.2017.12.004.

Cappiello, L., Engle, R. F., \& Sheppard, K. (2006). Asymmetric dynamics in the correlations of global equity and bond returns. Journal of Financial Econometrics, 4(4), 537-572. https://doi.org/10.1093/jjfinec/nb1005. Caramazza, F., Ricci, L., \& Salgado, R. (2004). International financial contagion in currency crises. Journal of International Money and Finance, 23(1), 51-70. https://doi.org/10.1016/j.jimonfin.2003.10.001.

Celik, S. (2012). The more contagion effect on emerging markets: The evidence of DCC-GARCH model. Economic Modelling, 29(5), 1946-1959. https://doi.org/10.1016/j.econmod.2012.06.011. 
Changqing, L., Chi, X., Cong, Y., \& Yan, X. (2015). Measuring financial market risk contagion using dynamic MRS-Copula models: The case of Chinese and other international stock markets. Economic Modelling, 51, 657-671. https://doi.org/10.1016/j.econmod.2015.09.021.

Chiang, T. C., Jeon, B. N., \& Li, H. (2007). Dynamic correlation analysis of financial contagion: Evidence from Asian markets. Journal of International Money and Finance, 26(7), 1206-1228. https://doi.org/10. 1016/j.jimonfin.2007.06.005.

Cronin, D., Flavin, T. J., \& Sheenan, L. (2016). Contagion in Eurozone sovereign bond markets? The good, the bad and the ugly. Economics Letters, 143, 5-8. https://doi.org/10.1016/j.econlet.2016.02.031.

Dash, S. R., \& Maitra, D. (2019). The relationship between emerging and developed market sentiment: A wavelet-based time-frequency analysis. Journal of Behavioral and Experimental Finance, 22, 135-150. https://doi.org/10.1016/j.jbef.2019.02.006.

De Pooter, M., Martin, R. F., \& Pruitt, S. (2012). The Effects of Official Bond Market Intervention in Europe. SSRN Electronic Journal. https://doi.org/10.2139/ssrn.2143326.

De Santis, R. A. (2012). The Euro area sovereign debt crisis: safe haven, credit rating agencies and the spread of the fever from Greece, Ireland and Portugal.

Dewandaru, G., Masih, R., \& Masih, A. M. M. (2016). What can wavelets unveil about the vulnerabilities of monetary integration? A tale of Eurozone stock markets. Economic Modelling, 52, 981-996. https://doi. org/10.1016/j.econmod.2015.10.037.

Dornbusch, R., Park, Y. C., Claessens, S., Dornbusch, R., Park, Y. C., \& Claessens, S. (2000). Contagion: Understanding How It Spreads. World Bank Research Observer, 15(2), 177-197.

Dungey, M., Fry, R. A., \& González-Hermosillo, B. (2011). \& Martin (Vol. L). Transmission of Financial Crises and Contagion: A Latent Factor Approach. Oxford University Press.

Dungey, M., \& Gajurel, D. (2014). Equity market contagion during the global financial crisis: Evidence from the world's eight largest economies. Economic Systems, 38(2), 161-177. https://doi.org/10.1016/j.ecosys. 2013.10.003.

Ehrmann, M., \& Fratzscher, M. (2017). Euro area government bonds - Fragmentation and contagion during the sovereign debt crisis. Journal of International Money and Finance, 70, 26-44. https://doi.org/10.1016/j. jimonfin.2016.08.005.

Ehrmann, M., Fratzscher, M., Gürkaynak, R. S., \& Swanson, E. T. (2011). Convergence and anchoring of yield curves in the euro area. Review of Economics and Statistics, 93(1), 350-364. https://doi.org/10.1162/ REST_a_00055.

Eichengreen, B., Rose, A., \& Wyplosz, C. (1996). Contagious currency crises: First tests. The Scandinavian Journal of Economics, 98(4), 463. https://doi.org/10.2307/3440879.

Engle, R. (2002). Dynamic conditional correlation: A simple class of multivariate generalized autoregressive conditional heteroskedasticity models. Journal of Business and Economic Statistics, 20(3), 339-350. https:// doi.org/10.1198/073500102288618487.

Falagiarda, M., \& Reitz, S. (2015). Announcements of ECB unconventional programs: Implications for the sovereign spreads of stressed euro area countries. Journal of International Money and Finance, 53, 276-295. https://doi.org/10.1016/j.jimonfin.2015.02.005.

Federal Reserve Board of St. (2009). Louis. A timeline of events and policy actions: The financial crisis. Forbes, K. (2012). The "Big C": Identifying Contagion. National Bureau of Economic Research. https://doi. org/10.3386/w18465.

Forbes, K. J., \& Rigobon, R. (2002). No contagion, only interdependence: Measuring stock market comovements. The Journal of Finance, 57(5), 2223-2261. https://doi.org/10.1111/0022-1082.00494.

Gallegati, M. (2012). A wavelet-based approach to test for financial market contagion. Computational Statistics and Data Analysis, 56(11), 3491-3497. https://doi.org/10.1016/j.csda.2010.11.003.

Georgoutsos, D., \& Migiakis, P. (2017). Market sentiment and contagion in Euro-area bond markets. In Handbook of Investors' Behavior during Financial Crises (pp. 241-256). Elsevier Inc. https://doi.org/https:// doi.org/10.1016/B978-0-12-811252-6.00014-1

Ghysels, E., Idier, J., Manganelli, S., \& Vergote, O. (2017). A high-frequency assessment of the ECB securities markets programme. Journal of the European Economic Association, 15(1), 218-243. https://doi. org/10.1093/jeea/jvw003.

Giordano, R., Pericoli, M., \& Tommasino, P. (2013). Pure or wake-up-call contagion? Another look at the EMU sovereign debt crisis. International Finance, 16(2), 131-160. https://doi.org/10.1111/j.1468-2362. 2013.12033.x.

Glick, R., \& Rose, A. K. (1999). Contagion and trade: Why are currency crises regional? Journal of International Money and Finance, 18(4), 603-617. https://doi.org/10.1016/S0261-5606(99)00023-6.

Gödl, M., \& Kleinert, J. (2016). Interest rate spreads in the eurozone: Fundamentals or sentiments? Review of World Economics, 152(3), 449-475. https://doi.org/10.1007/s10290-016-0252-2. 
Goldstein, M. (1998). The Asian financial crisis: Causes, cures, and systemic implications (Vol. 55). Peterson Institute.

Gupta, A. K. (2003). Multivariate skew t-distribution. Statistics: A Journal of Theoretical and Applied Statistics, 37(4), 359-363. https://doi.org/https://doi.org/10.1080/715019247

Haile, F., \& Pozo, S. (2008). Currency crisis contagion and the identification of transmission channels. International Review of Economics and Finance, 17(4), 572-588. https://doi.org/10.1016/j.iref.2007.05.005. Hansen, B. E. (1994). Autoregressive conditional density estimation. International Economic Review, 35(3), 705. https://doi.org/10.2307/2527081.

Kaminsky, G. L., \& Reinhart, C. M. (2000). On crises, contagion, and confusion. Journal of International Economics, 51(1), 145-168. https://doi.org/10.1016/S0022-1996(99)00040-9.

Kchaou, O., \& Bellalah, M. (2020). The contagion of the Greek debt crisis on the EMU sovereign bond markets: a Garch-DCC approach. International Journal of Entrepreneurship and Small Business, 39(1/2), $100-120$.

Kenourgios, D. (2014). On financial contagion and implied market volatility. International Review of Financial Analysis, 34, 21-30. https://doi.org/10.1016/j.irfa.2014.05.001.

Kenourgios, D., Naifar, N., \& Dimitriou, D. (2016). Islamic financial markets and global crises: Contagion or decoupling? Economic Modelling, 57, 36-46. https://doi.org/10.1016/j.econmod.2016.04.014.

Kenourgios, D., \& Padhi, P. (2012). Emerging markets and financial crises: regional, global or isolated shocks? Journal of Multinational Financial Management, 22(1-2), 24-38. https://doi.org/10.1016/j.mulfin. 2012.01.002.

Kodres, L. E., \& Pritsker, M. (2002). A Rational Expectations Model of Financial Contagion. The Journal of Finance, 57(2), 769-799. https://doi.org/10.1111/1540-6261.00441.

Krishnamurthy, A., Nagel, S., \& Vissing-Jorgensen, A. (2018). ECB policies involving government bond purchases: Impact and channels. Review of Finance, 22(1), 1-44. https://doi.org/10.1093/rof/rfx053.

Kumar, M. S., \& Persaud, A. (2002). Pure contagion and investors' shifting risk appetite: Analytical issues and impirical evidence. International Finance, 5(3), 401-436. https://doi.org/10.1111/1468-2362.00102.

Leschinski, C., \& Bertram, P. (2017). Time varying contagion in EMU government bond spreads. Journal of Financial Stability, 29, 72-91. https://doi.org/10.1016/j.jfs.2017.01.007.

Masson, P. (1999). Contagion: Macroeconomic models with multiple equilibria. Journal of International Money and Finance, 18(4), 587-602. https://doi.org/10.1016/S0261-5606(99)00016-9.

Masson, P. R. (1998). Contagion: Monsoonal effects, spillovers, and jumps between multiple equilibria. IMF Working Papers, 98(142), 1. https://doi.org/https://doi.org/10.5089/9781451856224.001

Missio, S., \& Watzka, S. (2011). Financial contagion and the European debt crisis. CESifo Working Paper Series. https://ideas.repec.org/p/ces/ceswps/_3554.html

N'Diaye, P., Zhang, P., \& Zhang, W. (2010). Structural reform, intra-regional trade, and medium-term growth prospects of East Asia and the Pacific-Perspectives from a new multi-region model. Journal of Asian Economics, 21(1), 20-36. https://doi.org/10.1016/j.asieco.2009.05.005.

Nelson, D. B. (1991). Conditional heteroskedasticity in asset returns: A new approach. Econometrica, 59(2), 347. https://doi.org/10.2307/2938260.

Neri, S., \& Ropele, T. (2015). The macroeconomic effects of the sovereign debt crisis in the euro area. Temi Di Discussione (Economic Working Papers).

Pappas, V., Ingham, H., Izzeldin, M., \& Steele, G. (2016). Will the crisis "tear us apart"? Evidence from the EU. International Review of Financial Analysis, 46, 346-360. https://doi.org/10.1016/j.irfa.2015.09.010.

Pentecost, E. J., Du, W., Bird, G., \& Willett, T. (2019). Contagion from the crises in the Euro-zone: where, when and why? European Journal of Finance, 25(14), 1309-1327. https://doi.org/10.1080/1351847X.2019. 1589552.

Pericoli, M., \& Sbracia, M. (2003). A primer on financial contagion. Journal of Economic Surveys, 17(4), 571-608. https://doi.org/10.1111/1467-6419.00205.

Philippas, D., \& Siriopoulos, C. (2013). Putting the "C" into crisis: Contagion, correlations and copulas on EMU bond markets. Journal of International Financial Markets, Institutions and Money, 27(1), 161-176. https://doi.org/10.1016/j.intfin.2013.09.008.

Pragidis, I. C., Aielli, G. P., Chionis, D., \& Schizas, P. (2015). Contagion effects during financial crisis: Evidence from the Greek sovereign bonds market. Journal of Financial Stability, 18, 127-138. https://doi. org/10.1016/j.jfs.2015.04.001.

Rodriguez, J. C. (2007). Measuring financial contagion: A Copula approach. Journal of Empirical Finance, 14(3), 401-423. https://doi.org/10.1016/j.jempfin.2006.07.002.

Rotta, P. N., \& Valls Pereira, P. L. (2016). Analysis of contagion from the dynamic conditional correlation model with Markov Regime switching. Applied Economics, 48(25), 2367-2382. https://doi.org/10.1080/ 00036846.2015.1119794. 
Saka, O., Fuertes, A. M., \& Kalotychou, E. (2015). ECB policy and Eurozone fragility: Was de grauwe right? Journal of International Money and Finance, 54, 168-185. https://doi.org/10.1016/j.jimonfin.2015.03.002. Samitas, A., \& Tsakalos, I. (2013). How can a small country affect the European economy? The Greek contagion phenomenon. Journal of International Financial Markets, Institutions and Money, 25(1), 18-32. https://doi.org/10.1016/j.intfin.2013.01.005.

Sander, H., \& Kleimeier, S. (2003). Contagion and causality: An empirical investigation of four Asian crisis episodes. Journal of International Financial Markets, Institutions and Money, 13(2), 171-186. https://doi. org/10.1016/S1042-4431(02)00043-4.

Schwaab, B., \& Eser, F. (2013). Assessing asset purchases within the ECB's securities markets programme. Working Paper Series. https://ideas.repec.org/p/ecb/ecbwps/20131587.html

Sensoy, A., Nguyen, D. K., Rostom, A., \& Hacihasanoglu, E. (2019). Dynamic integration and network structure of the EMU sovereign bond markets. Annals of Operations Research, 281(1-2), 297-314. https:// doi.org/10.1007/s10479-018-2831-1.

Smeets, D. (2016). Financial Contagion During the European Sovereign Debt Crisis. Journal of Economic \& Financial Studies, 4(02), 46. https://doi.org/https://doi.org/10.18533/jefs.v4i02.199

Szczerbowicz, U. (2015). The ECB Unconventional Monetary Policies: Have They Lowered Market Borrowing Costs for Banks and Governments? International Journal of Central Banking, 11(4), 91-127. https:// ideas.repec.org/a/ijc/ijcjou/y2015q5a3.html

Tamakoshi, G., \& Hamori, S. (2013). An asymmetric dynamic conditional correlation analysis of linkages of European financial institutions during the Greek sovereign debt crisis. European Journal of Finance, 19(10), 939-950. https://doi.org/10.1080/1351847X.2012.712921.

Tamakoshi, G., \& Hamori, S. (2014). The conditional dependence structure of insurance sector credit default swap indices. North American Journal of Economics and Finance, 30, 122-132. https://doi.org/10.1016/j. najef.2014.09.002.

Terasvirta, T. (1994). Specification, estimation, and evaluation of smooth transition autoregressive models. Journal of the American Statistical Association, 89(425), 208. https://doi.org/10.2307/2291217.

Vácha, L., Šmolík, F., \& Baxa, J. (2019). Comovement and disintegration of EU sovereign bond markets during the crisis. International Review of Economics \& Finance, 64, 541-556. https://doi.org/10.1016/j.iref. 2019.09.004.

Wen, X., Wei, Y., \& Huang, D. (2012). Measuring contagion between energy market and stock market during financial crisis: A copula approach. Energy Economics, 34(5), 1435-1446. https://doi.org/10.1016/j.eneco. 2012.06.021.

Zhang, Z., Zhang, \& Zhiwei. (2008). Can Demand from China Shield East Asian Economies from Global Slowdown? https://econpapers.repec.org/RePEc:hkg:wpaper:0819

Zhu, Y., Yang, F., \& Ye, W. (2018). Financial contagion behavior analysis based on complex network approach. Annals of Operations Research, 268(1-2), 93-111. https://doi.org/10.1007/s10479-016-2362-6.

Publisher's Note Springer Nature remains neutral with regard to jurisdictional claims in published maps and institutional affiliations. 